\title{
The impact of lamb diets containing either barley or corn on growth performance and carcass quality
}

\author{
M. Ata ${ }^{1}$ and Belal S. Obeidat ${ }^{2}$ iD
}

1. Department of Animal Production and Protection, Faculty of Agriculture, Jerash University, Jerash 26150, Jordan; 2. Department of Animal Production, Faculty of Agriculture, Jordan University of Science and Technology, Irbid 22110, Jordan.

Corresponding author: Belal S. Obeidat, e-mail: bobeidat@just.edu.jo

Co-author: MA: m.atta@jpu.edu.jo

Received: 19-01-2021, Accepted: 26-04-2021, Published online: 10-06-2021

doi: www.doi.org/10.14202/vetworld.2021.1487-1491 How to cite this article: Ata M, Obeidat BS (2021) The impact of lamb diets containing either barley or corn on growth performance and carcass quality, Veterinary World, 14(6): 1487-1491.

\begin{abstract}
Background and Aim: Grains, such as barley (BAR) and corn (CORN), are major energy sources for small ruminants. This study aimed to assess the impact of feeding either BAR or CORN-based diets on growth performance and carcass characteristics.

Materials and Methods: Awassi male lambs, average body weight of $20.4 \pm 0.49 \mathrm{~kg}$, were chosen randomly. Lambs were acclimated for 10 days and assigned to one of two diets (1) BAR and (2) CORN. Feeding continued for 70 days with 60 days of data collection. Daily intake was recorded. Measurements of body weight were taken starting from day 1 then once per week throughout the study period. On day 40, six lambs were randomly chosen from each group and placed in metabolism cages to assess digestibility and $\mathrm{N}$ balance. Lambs were slaughtered on the last day of the study to evaluate carcass characteristics and meat quality.
\end{abstract}

Results: Neutral and acid detergent fiber and ether extract intake were greater $(\mathrm{p} \leq 0.05)$ for lambs fed the BAR diets. Nitrogen loss in feces tended to be greater $(\mathrm{p}=0.09)$ for the CORN diet. Eye muscle depth $(\mathrm{mm})$ tended to be greater $(p=0.07)$ for the BAR diet. Nutrient digestibility, daily weight gain, carcass characteristics, and meat quality were not different $(\mathrm{p} \geq 0.1)$ between diets.

Conclusion: The results herein demonstrate that feeding BAR grain improved nutrient intake efficiency and consistency and did not affect weight gain and carcass traits. BAR-based diets might be a useful alternative to CORN for feeding growing lambs.

Keywords: Awassi lambs, barley, carcass, corn, performance.

\section{Introduction}

The sheep population in Jordan is estimated to be 3 million head [1]. Awassi is the predominant breed [2]. Awassi sheep are distributed in more than 30 countries due to their superior meat and milk production. The bred is considered transboundary and international [3]. The productivity of Awassi lambs depends on feed. Whole grains, such as barley (BAR) and corn (CORN), are the main ingredients in lamb diets since the availability of good quality forage in Jordan is limited by the harsh environment [4]. The nutritive value of BAR and CORN is reflected mainly in energy content; protein is considered of secondary importance [5]. In Jordan, CORN costs 50\%-80\% more than BAR. The latter is produced locally while CORN is imported. Consequently, using CORN in greater proportions in feed is less economical compared to feed formulated with high BAR content [6].

Copyright: Ata and Obeidat. Open Access. This article is distributed under the terms of the Creative Commons Attribution 4.0 International License (http://creativecommons.org/licenses/ by/4.0/), which permits unrestricted use, distribution, and reproduction in any medium, provided you give appropriate credit to the original author(s) and the source, provide a link to the Creative Commons license, and indicate if changes were made. The Creative Commons Public Domain Dedication waiver (http:// creativecommons.org/publicdomain/zero/1.0/) applies to the data made available in this article, unless otherwise stated.
Mixing different grains containing varying amounts of degradable carbohydrate improve growth performance and efficiency in ruminants $[7,8]$. Grain ratios for improving microbial activity in ruminants rely on the management of carbohydrate and protein content [9]. Animal performance and ruminal starch fermentation were increased by combining slowly and rapidly fermenting grains compared to feed using single grains [10]. Further, starch and protein from BAR are fermented more quickly and efficiently in the rumen than CORN starch and protein [11]. BAR also stimulates energy and nitrogen release, thus improving the absorption of microbial nutrients. Accordingly, BAR might be a good replacement for protein sources that are used in ruminant diets [12].

The study hypothesis was that feeding whole grain-based diets (BAR vs. CORN) will improve lamb performance, carcass, and meat characteristics. This study aimed to investigate the effects of feeding either BAR or CORN on intake, nutrient digestibility, performance, and meat and carcass quality of Awassi lambs.

\section{Materials and Methods}

\section{Ethical approval}

This study was approved by Institutional Animal Care and Use Committee, Jordan University of Science and Technology (JUST). 


\section{Study period and location}

The study was conducted from January to April 2020 at the Agriculture Center for Research and Production of JUST. Samples collected during the study were analyzed at the Department of Animal Production Laboratories.

\section{Study procedures and sample analysis}

Thirty Awassi male lambs, $20.4 \pm 0.49 \mathrm{~kg}$ average body weight, were assigned randomly into two groups using a completely randomized design. Lambs were fed either a BAR-based diet or a CORN-based diet (Table-1). Diets were prepared to provide fattening Awassi lambs with similar crude protein (CP) content $(160 \mathrm{~g} / \mathrm{kg}$ CP: Dry matter (DM) basis) [13,14]. Lambs individually housed in specially designed pens $(1.5 \mathrm{~m} \times 0.75 \mathrm{~m})$ and fed twice per day at 0900 and $1600 \mathrm{~h}$ with equal meals. Feeding continued for 70 days, following an acclimation and adaptation period of 10 days. Diets were offered every day to allow ad libitum intake. Uneaten feed was weighed throughout the study and stored at $-20^{\circ} \mathrm{C}$ for analysis. Lambs were weighed on day 1 then weekly until the end of the experiment. On day 40, six animals were chosen randomly from each group and housed individually in metabolism cages $(1.05 \mathrm{~m} \times 0.80 \mathrm{~m})$ for evaluating digestibility. Five days of acclimation to cages were followed by 5 days of sample collection. Amounts of feed intake and refusal during the digestibility study were recorded and sampled for analysis. Collected feces were weighed daily. About $100 \mathrm{~g} / \mathrm{kg}$ of feces was stored for subsequent analyses.

Samples of feedstock and uneaten residual were dried at $55^{\circ} \mathrm{C}$, weighed, and ground for further analysis. Feed, residual, and feces were analyzed for DM, CP, ether extract (EE), neutral detergent fiber (NDF), and acid detergent fiber (ADF). Analysis of samples used AOAC [15] procedures for $\mathrm{DM}$ with an air-forced oven set to $100^{\circ} \mathrm{C}$ for $24 \mathrm{~h}, \mathrm{CP}$ (Kjeldahl procedure) and EE (Soxtec procedure, Soxtec System HT 1043 Extraction Unit, Tecator, Box 70, Hoganäs, Sweden) were also measured. Analytical procedures for NDF and ADF were performed according to Van Soest et al. [16] with adjustments for use in the fiber analyzer (Ankom2000) (Ankom Technology Cooperation, Fairport, NY, USA). Analysis of NDF used sodium sulfite and alpha-amylase (heat stable). NDF was then calculated using residual ash content.

\section{Slaughtering procedures, carcass, and meat quality evaluation}

Slaughtering was performed at the Agriculture and Production Facilities Center at the end of 70 days. Lamb fasted body weight was recorded $18 \mathrm{~h}$ after the last meal. Lambs were slaughtered by qualified personnel at $0900 \mathrm{~h}$ as previously described by Obeidat [17]. Immediately after slaughter, weight was recorded as hot carcass weight. After chilling at $4^{\circ} \mathrm{C}$
Table-1: Ingredients and chemical composition of diets containing either BAR or CORN grains fed to Awassi lambs.

\begin{tabular}{lcc}
\hline Item & \multicolumn{2}{c}{ Diets } \\
\cline { 2 - 3 } & BAR & CORN \\
\hline Ingredients (g/kg DM) & 500 & 0 \\
BAR grain & 0 & 500 \\
CORN grain & 150 & 180 \\
Soybean meal & 110 & 170 \\
Alfalfa hay & 220 & 130 \\
Wheat straw & 10.0 & 10.0 \\
Salt & 9.0 & 9.0 \\
Limestone & 1.0 & 1.0 \\
Vitamin-mineral premix 1 & 426 & 462 \\
Feed cost/ton (US\$) 2 & & \\
Nutrients (g/kg DM) & 90.8 & 90.4 \\
Dry matter & 160 & 160 \\
Crude protein & 334 & 248 \\
Neutral detergent fiber & 196 & 155 \\
Acid detergent fiber & 38.9 & 39.4 \\
Ether extract &
\end{tabular}

${ }^{1}$ Composition per kg contained (Vitamin A, 600,000

IU; Vitamin D3, 200,000 IU; Vitamin E, 75 mg, Vitamin K3, 200 mg; Vitamin B1, 100 mg; Vitamin B5,

$500 \mathrm{mg}$; lysine $0.5 \%$; DL-methionine, $0.15 \%$; manganese oxide, $4000 \mathrm{mg}$; ferrous sulfate, $15,000 \mathrm{mg}$; zinc oxide, 7000; magnesium oxide, $4000 \mathrm{mg}$; potassium iodide, $80 \mathrm{mg}$; sodium selenite, $150 \mathrm{mg}$; copper sulfate, $100 \mathrm{mg}$; cobalt phosphate, $50 \mathrm{mg}$, dicalcium phosphate, $10,000 \mathrm{mg} .{ }^{2}$ Calculated based on the current prices. $\mathrm{BAR}=$ Barley, $\mathrm{CORN}=$ Corn, $\mathrm{DM}=$ Dry matter

for $24 \mathrm{~h}$, cold carcass weight was recorded. Dressing percentage used cold carcass weight divided by fasted live weight. Non-edible parts of the carcass were removed and weighed immediately after slaughter. Linear dimensions and longissimus muscle measurements were recorded using chilled carcasses [17]. Carcasses were divided into four parts - shoulder, rack, loin, and leg cuts. Loin cuts were dissected to remove the longissimus muscle. Muscle samples were packed and stored in vacuum pack bags at $-20^{\circ} \mathrm{C}$ for 2 weeks until evaluation.

Meat quality variables of $\mathrm{pH}$, cooking water loss, water holding capacity (WHC), shear force values, and color (CIE L*a*b* coordinates) were measured. Frozen longissimus muscles were thawed at $4^{\circ} \mathrm{C}$ overnight using a chiller. Meat quality measurement used muscle tissue after cutting slices of exact thickness [18]. Color measurements used meat slices $15 \mathrm{~mm}$ thick with a colorimeter (12MM Aperture U 59730-30, Cole-Parameter International, Accuracy Microsensors Inc., Pittsford, NY, USA). Meat slices were distributed on a polystyrene tray and covered with a permeable film to allow access to oxygen for $2 \mathrm{~h}$ at $4^{\circ} \mathrm{C}$. Meat slices $25 \mathrm{~mm}$ thick were used for cooking loss measurements. Slices were weighed, distributed into plastic bags, and cooked for $90 \mathrm{~min}$ using a water bath at $75^{\circ} \mathrm{C}$. After cooking, slices were again weighed to calculate percentage water loss. Cooked slices were kept overnight at $4^{\circ} \mathrm{C}$, and six cores of about $1-\mathrm{mm}^{3}$ were cut from the slices to measure shear 
force values. A perpendicular to the direction of muscle fiber known as a Warner-Bratzler shear blade was used. $\mathrm{pH}$ was measured using $\mathrm{pH}$ meter after thawing meat samples. WHC used $5 \mathrm{~g}$ of raw meat chopped into tiny pieces and placed between two filter papers and two quartz plates. Tissues were squeezed under a $2500 \mathrm{~g}$ weight for $5 \mathrm{~min}$ to remove intracellular water. Meat samples were removed and weighed. WHC was calculated as WHC \% = (initial weight - final weight) $\times 100 /$ initial weight.

\section{Statistical analysis}

Data were analyzed using the MIXED procedure in SAS (version 8.1, 2000, SAS Inst. Inc., Cary, NC, USA). Fixed effects included only treatments for all data. Individual lambs were the random variable. Least square means were used to identify significance and differences among means at $p \leq 0.05$.

\section{Results}

Nutrient intake improved for lambs consuming BAR (Table-2). DM and CP intake were similar $(p=0.9)$ for the two experimental diets. Intakes of $\mathrm{NDF}$ and ADF were greater $(\mathrm{p}<0.05)$ and the intake of EE was lower $(p<0.05)$ for lambs who consumed BAR compared to CORN.

Neither BAR nor CORN diets affected nutrient digestibility or $\mathrm{N}$ balance measurements, except for $\mathrm{N}$ lost in feces $($ Table-3). A tendency $(\mathrm{p}<0.09)$ was noticed for greater $\mathrm{N}$ loss in lambs fed CORN compared to BAR. ADG and total weight gain were not affected by diet, even though initial weights tended to be greater $(\mathrm{p}=0.06)$ for the BAR group versus the CORN group (Table-4). Carcass and non-edible carcass characteristics were not affected $(p>0.05)$ by diet (Table-5). Carcass linear dimensions were almost the same for the two groups, except for eye muscle depth. This parameter tended to be greater $(\mathrm{p}=0.07)$ for lambs fed BAR (Table-6). Meat quality was also not affected $(p<0.05)$ between lambs from the two feeding groups (Table-7).

\section{Discussion}

We hypothesized that lambs fed whole grainbased diets (BAR and CORN) would display better

Table-2: Effects of feeding either BAR or CORN grains on nutrient intakes of growing Awassi lambs.

\begin{tabular}{lcccc}
\hline Item & \multicolumn{4}{c}{ Diets } \\
\cline { 2 - 5 } & $\begin{array}{c}\text { BAR } \\
(\mathbf{n = 1 5})\end{array}$ & $\begin{array}{c}\text { CORN } \\
(\mathbf{n = 1 5})\end{array}$ & SEM & p-value \\
\hline Nutrient intake & 1064 & 1066 & 40.8 & 0.9698 \\
$\begin{array}{l}\text { Dry matter, g/days } \\
\text { Crude protein, g/days }\end{array}$ & 171 & 171 & 6.54 & 0.9887 \\
$\begin{array}{l}\text { Neutral detergent } \\
\text { fiber, g/days }\end{array}$ & 355 & 264 & $11.85<0.0001$ \\
$\begin{array}{l}\text { Acid detergent fiber, } \\
\text { g/days }\end{array}$ & 208 & 165 & 7.13 & 0.0005 \\
$\begin{array}{l}\text { Ether extract, g/days } \\
\text { BAR=Barley, CORN=Corn, SEM=Standard error of the } \\
\text { mean }\end{array}$ & 41.4 & 42.0 & 1.60 & 0.0005 \\
\hline
\end{tabular}

nutrient digestibility, growth performance, and feed utilization. Diets were designed to provide similar $\mathrm{CP}$ content to compare grains at similar dietary DM levels. A positive effect was observed by adding high moisture CORN with whole-grain diets. Such diets improved feed efficiency and daily weight gain in

Table-3: Effects of feeding either BAR or CORN grains on nutrient digestibility and $\mathrm{N}$ balance of Awassi lambs.

\begin{tabular}{lcccc}
\hline Item & \multicolumn{4}{c}{ Diets } \\
\cline { 2 - 5 } & $\begin{array}{c}\text { BAR } \\
(\mathbf{n = 6 )}\end{array}$ & $\begin{array}{c}\text { CORN } \\
(\mathbf{n = 6 )}\end{array}$ & SEM & p-value \\
\hline Digestibility & & & & \\
DM & 80.5 & 83.7 & 2.34 & 0.2427 \\
CP & 80.8 & 81.6 & 2.56 & 0.7690 \\
NDF & 66.2 & 65.7 & 4.48 & 0.9234 \\
ADF & 61.2 & 60.7 & 1.27 & 0.7890 \\
EE & 86.6 & 83.6 & 2.55 & 0.2314 \\
N balance & & & & \\
N intake, g/d & 27.3 & 28.9 & 1.48 & 0.3126 \\
N lost in feces, g/d & 5.3 & 6.9 & 0.64 & 0.0962 \\
N lost in urine, g/d & 10.2 & 9.4 & 1.52 & 0.7216 \\
Retained N, g/d & 11.8 & 12.7 & 1.48 & 0.6866 \\
N retention, \% & 44.1 & 43.9 & 5.51 & 0.9789 \\
\hline
\end{tabular}

$\mathrm{BAR}=$ Barley, $\mathrm{CORN}=$ Corn, $\mathrm{DM}=$ Dry matter, $\mathrm{CP}=$ Crude protein, NDF=Neutral detergent fiber, $A D F=$ Acid detergent fiber, $E E=E$ ther extract

Table-4: Effects of feeding either BAR or CORN grains on growth performance of Awassi lambs.

\begin{tabular}{lcccc}
\hline Item & \multicolumn{4}{c}{ Diets } \\
\cline { 2 - 5 } & $\begin{array}{c}\text { BAR } \\
(\mathbf{n = 1 5})\end{array}$ & $\begin{array}{c}\text { CORN } \\
(\mathbf{n = 1 5 )}\end{array}$ & SEM & p-value \\
\hline Initial weight, kg & 20.7 & 20.2 & 0.49 & 0.0608 \\
Final weight, kg & 33.5 & 33.5 & 1.09 & 0.9830 \\
Average daily gain, g & 213 & 222 & 16.2 & 0.7045 \\
Total gain, kg & 12.8 & 13.3 & 0.97 & 0.7045 \\
\hline
\end{tabular}

BAR=Barley, $\mathrm{CORN}=$ Corn, SEM $=$ Standard error of the mean

Table-5: Effects of feeding either BAR or CORN grains on carcass, non-carcass components, carcass cut weights and percentages, and dissected loin of Awassi lambs.

\begin{tabular}{lcccc}
\hline \multirow{2}{*}{ Item } & \multicolumn{4}{c}{ Diets } \\
\cline { 2 - 6 } & $\begin{array}{c}\text { BAR } \\
(\mathbf{n = 1 5})\end{array}$ & $\begin{array}{c}\text { CORN } \\
(\mathbf{n = 1 5})\end{array}$ & SEM & p-value \\
\hline Fasting live weight $(\mathrm{kg})$ & 32.9 & 30.9 & 1.16 & 0.2500 \\
Hot carcass weight $(\mathrm{kg})$ & 15.5 & 14.9 & 0.63 & 0.5321 \\
Cold carcass weight $(\mathrm{kg})$ & 15.1 & 14.4 & 0.59 & 0.4178 \\
Dressing percentage & 45.7 & 46.8 & 0.70 & 0.2268 \\
Non-carcass & 1.39 & 1.41 & 0.036 & 0.5351 \\
components $(\mathrm{kg})$ & & & & \\
Carcass cut weights $(\mathrm{kg})$ & 12.8 & 12.4 & 0.49 & 0.5741 \\
Fat tail $(\mathrm{kg})$ & 1.79 & 1.72 & 0.136 & 0.7047 \\
Loin weight $(\mathrm{g})$ & 1053 & 994 & 69.9 & 0.5594 \\
Subcutaneous fat $(\mathrm{g} / 100 \mathrm{~g})$ & 11.53 & 12.20 & 1.365 & 0.7336 \\
Intermuscular fat $(\mathrm{g} / 100 \mathrm{~g})$ & 2.88 & 2.71 & 0.395 & 0.7721 \\
Total fat $(\mathrm{g} / 100 \mathrm{~g})$ & 14.37 & 14.91 & 1.558 & 0.8120 \\
Total meat $(\mathrm{g} / 100 \mathrm{~g})$ & 58.24 & 56.67 & 1.373 & 0.4356 \\
Total bone $(\mathrm{g} / 100 \mathrm{~g})$ & 26.21 & 26.40 & 1.192 & 0.9140 \\
Meat to bone ratio & 2.27 & 2.25 & 0.127 & 0.9215 \\
Meat to fat ratio & 5.11 & 4.93 & 0.780 & 0.8798 \\
\hline BAR=Barley, CORN=Corn & & & & \\
\hline
\end{tabular}

Veterinary World, EISSN: 2231-0916 
Table-6: Effects of feeding either BAR or CORN grains on carcass leaner dimensions of Awassi lambs.

\begin{tabular}{|c|c|c|c|c|}
\hline \multirow[t]{2}{*}{ Item } & \multicolumn{4}{|c|}{ Diets } \\
\hline & $\begin{array}{c}\text { BAR } \\
(n=15)\end{array}$ & $\begin{array}{c}\text { CORN } \\
(n=15)\end{array}$ & SEM & p-value \\
\hline $\begin{array}{l}\text { Leg fat depth } \\
(L 3)(\mathrm{mm})\end{array}$ & 3.50 & 3.57 & 0.458 & 0.9194 \\
\hline $\begin{array}{l}\text { Tissue depth } \\
(G R)(\mathrm{mm})\end{array}$ & 9.47 & 8.73 & 0.519 & 0.3348 \\
\hline $\begin{array}{l}\text { Rib fat depth } \\
(J)(\mathrm{mm})\end{array}$ & 2.84 & 2.50 & 0.397 & 0.5545 \\
\hline $\begin{array}{l}\text { Eye muscle width } \\
\text { (A) }(\mathrm{mm})\end{array}$ & 49.9 & 48.8 & 0.8766 & 0.3955 \\
\hline $\begin{array}{l}\text { Eye muscle depth } \\
(B)(\mathrm{mm})\end{array}$ & 21.19 & 19.73 & 0.5394 & 0.0713 \\
\hline Fat depth $(C)(\mathrm{mm})$ & 2.00 & 2.17 & 0.188 & 0.5407 \\
\hline $\begin{array}{l}\text { Shoulder fat depth } \\
(\mathrm{S} 2)(\mathrm{mm})\end{array}$ & 2.03 & 1.77 & 0.250 & 0.4625 \\
\hline
\end{tabular}

$\mathrm{BAR}=$ Barley, $\mathrm{CORN}=$ Corn, SEM $=$ Standard error of the mean

Table-7: Effects of feeding either BAR or CORN grains on meat quality of Awassi lambs.

\begin{tabular}{lcccc}
\hline Item & \multicolumn{4}{c}{ Diets } \\
\cline { 2 - 5 } & $\begin{array}{c}\text { BAR } \\
(\mathbf{n = 1 5})\end{array}$ & $\begin{array}{c}\text { CORN } \\
(\mathbf{n = 1 5})\end{array}$ & SEM & p-value \\
\hline $\mathrm{pH}$ & 5.83 & 5.82 & 0.015 & 0.5730 \\
Cooking loss $(\mathrm{g} / 100 \mathrm{~g})$ & 38.4 & 38.3 & 0.92 & 0.8524 \\
Water holding capacity & 23.7 & 24.9 & 1.23 & 0.5031 \\
$(\mathrm{~g} / 100 \mathrm{~g})$ & & & & \\
Shear force $\left(\mathrm{kg} / \mathrm{cm}^{2}\right)$ & 9.0 & 9.6 & 0.51 & 0.3822 \\
Color coordinates & & & & \\
$\quad$ L* (whiteness) & 35.1 & 43.2 & 5.71 & 0.3315 \\
a* (redness) & 2.47 & 2.45 & 0.157 & 0.8650 \\
b* (yellowness) & 17.2 & 16.9 & 0.68 & 0.7717 \\
\hline BAR & & &
\end{tabular}

$\mathrm{BAR}=$ Barley, $\mathrm{CORN}=$ Corn, SEM $=$ Standard error of the mean

ruminants [19]. CORN starch is less well digested in the rumen than starch from BAR. CORN starch digestibility might increase following processing, while digestibility of BAR is not affected [11].

Further, a noticeable finding in the previous studies is improvement in ruminal and total intestinal tract starch digestion after adding grains to the feed. Thus, feed utilization and efficiency were partly improved in the current study. These improvements were the result of integrating dietary energy and protein from grainbased formulated diets. The similarity in outcomes between diets might be due to insufficiently processed grains.

An improvement in NDF and ADF intake was observed with lambs fed BAR. Conversely, intake of EE was reduced. Boss and Bowman [20] reported similar findings for BAR-fed steers that showed greater feed efficiency compared with steers fed dryrolled CORN. Other authors noticed no effect on nutrient intake after feeding BAR or CORN to ruminants $[21,22]$. In contrast, an improvement in nutrient intake for animals fed CORN-based diets compared to BAR is reported $[7,10,23,24]$. This increase in intake efficiency may reflect the processing method, which, in turn, affects its digestibility in the rumen. Moreover, higher nutrient intake in ruminants consuming CORNbased diets is explained by higher starch degradability of BAR compared to CORN. This finding suggests a change in ruminal $\mathrm{pH}$ resulting in decreasing cellulolytic bacteria counts and accompanying decreased digestibility of nutrients [25].

Nutrient's digestibility, nitrogen balance, weight gain, and carcass quality were not affected by diet in the current study. Johnson et al. [7] observed an improvement in nutrient digestibility for steers consuming BAR versus CORN, though daily weight gain and body weight of steers did not differ. Conversely, final weight and daily weight gain were greater for lambs fed CORN versus BAR diets [10]. The authors suggest higher ruminal $\mathrm{pH}$ and better starch ruminal outflow [26] in ruminants consuming CORN- versus BAR-based diets.

Carcass characteristics were enhanced by consuming CORN-based diets, consistent with the previous studies [7,24,27]. In the current study, total meat and eye muscle depth were slightly improved in lambs fed BAR. The opposite result was reported by Petit [24] where total tissue depth was slightly enhanced by feeding CORN compared to BAR. A slight increment in body weight in the form of meat rather than fat or bone was observed after feeding with BAR compared to CORN.

\section{Conclusion}

Feeding BAR improved nutrient intake efficiency and consistency for enhanced weight gain and carcass traits. BAR can be used to replace CORN grain in feed for growing lambs.

\section{Authors' Contributions}

BSO and MA: Designed, supervised, and drafted the manuscript. Both authors read and approved the final manuscript.

\section{Acknowledgments}

The authors wish to thank the Deanship of Scientific Research at Jordan University of Science and Technology for the financial support of this project (176/2019).

\section{Competing Interests}

The authors declare that they have no competing interests.

\section{Publisher's Note}

Veterinary World remains neutral with regard to jurisdictional claims in published institutional affiliation.

\section{References}

1. DOS. (2018) Department of Statistics, Livestock Reports, Amman, Jordan.

2. Gootwine, E. (2011) Mini review: Breeding Awassi and 
Assaf sheep for diverse management conditions. Trop. Anim. Health Prod., 43(7): 1289-1296.

3. FAO. (2015) The second report on the State of the World's Animal Genetic Resources for Food and Agriculture. In: Scher, B.D. and Pilling, D., editors. FAO Commission on Genetic Resources for Food and Agriculture Assessment, Rome. Available from: http://www.fao.org/3/a-i4784e.pdf. Retrieved on 20-12-2020.

4. Obeidat, B.S., Subih, H.S. and Ata, M. (2020) Protein supplementation improves performance of lambs fed low-quality forage. Animals, 10(1): 51 .

5. Alagon, G., Arce, O.N., Martínez-Paredes, E., Ródenas, L., Moya, V.J., Blas, E., Cervera, C. and Pascual, J.J. (2016) Nutritive value of distillers dried grains with solubles from barley, corn and wheat for growing rabbits. Anim. Feed Sci. Technol., 222(12): 217-226.

6. Tricase, C., Amicarelli, V., Lamonaca, E. and Rana, R.L. (2018) Economic analysis of the barley market and related uses. In: Tadele, Z., editor. Grasses as Food and Feed. IntechOpen, London, UK. p25-46.

7. Johnson, J.A., Sutherland, B.D., McKinnon, J.J., McAllister, T.A. and Penner, G.B. (2019) Use of barley or corn silage when fed with barley, corn, or a blend of barley and corn on growth performance, nutrient utilization, and carcass characteristics of finishing beef cattle. Transl. Anim. Sci., 4(1): 129-140.

8. Rodríguez-Hernándeza, K., Maldonado-Jáqueza, J.A., Granados-Riverab, L.D., Sánchez-Duartea, J.I., Domínguez-Martínezc, P.A., Torres-Hernándezd, G. and Argüelles-Verdugo, E.A. (2019) Finishing lambs using an integral feed under a restricted-feeding program in an intensive production system in Northern Mexico. Austral. J. Vet. Sci., 51(3): 105-111.

9. Nikkhah, A., Alikhani, M. and Amanlou, H. (2004) Effects of feeding ground or steam-flaked broom sorghum and ground barley on performance of dairy cows in mid lactation. J. Dairy Sci., 87(1): 122-130.

10. Haddad, S. and Nasr, R. (2007) Partial replacement of barley grain for corn grain: Associative effects on lambs' growth performance. Small Rumin. Res., 72(2-3): 92-95.

11. Gomez, L.M., Posada, S.L. and Olivera, M. (2016) Starch in ruminant diets: A review. Rev. Colomb. Cienc. Pecu., 29(2): 77-90.

12. Nikkhah, A. (2012) Barley grain for ruminants: A global treasure or tragedy. J. Anim. Sci. Biotechnol., 3(1): 22-30.

13. NRC. (2007) Nutrient Requirements of Small Ruminants: Sheep, Goats, Cervids, and New World Camelids. National Academy of Sciences Press, Washington, DC, USA.

14. Obeidat, B.S. (2020) The inclusion of black cumin meal improves growth performance of growing Awassi lambs. Vet. Sci., 7(2): 40.

15. AOAC. (1990) Official Methods of Analysis. $15^{\text {th }}$ ed.
Association Analytical Chemist, Arlington, VA, USA.

16. van Soest, P.J., Robertson, J.B. and Lewis, B.A. (1991) Methods for dietary fiber, neutral detergent fiber, and non-starch polysaccharides in relation to animal nutrition. J. Dairy Sci., 74(10): 473-481.

17. Obeidat, B.S. (2021) The inclusion of black cumin meal improves carcass characteristics of growing Awassi lambs. Vet. World, 14(1): 237-241.

18. Obeidat, B.S., Mayyas, M.A., Abduallah, A.Y., Awawdeh, M.S., Qudsieh, R.I., Obeidat, M.D., Nusairat, B.M., Mahmoud, K.Z., Haddad, S.G., Al-Lataifeh, F.A., Ata, M., Abu Ishmais, M.A. and Aljamal, A.E. (2019) The potential use of layer litter in Awassi lamb diet: Its effects on carcass characteristics and meat quality. Animals, 9(10): 782.

19. Huck, G.L., Kreikemeier, K.K., Kuhl, G.L., Eck, T.P. and Bolsen, K.K. (1998) Effects of feeding combinations of steam-flaked grain sorghum and steam-flaked, high-moisture, or dry-rolled corn on growth performance and carcass characteristics in feedlot cattle. J. Anim. Sci., 76(12): 2984-2990.

20. Boss, D.L. and Bowman, J.G. (1996) Barley varieties for finishing steers: II. Ruminal characteristics and rate, site, and extent of digestion. J. Anim. Sci., 74(8): 1973-1981.

21. Mathison, G.W. and Engstrom, D.F. (1995) Ad libitum versus restricted feeding of barley-and corn-based feedlot diets. Can. J. Anim. Sci., 75(4): 637-640.

22. Martin-Orue, S.M., Balcells, J., Vicente, F. and Castrillo, C. (2000) Influence of dietary rumen-degradable protein supply on rumen characteristics and carbohydrate fermentation in beef cattle offered high-grain diets. Anim. Feed Sci. Technol., 88(1-2): 59-77.

23. Nelson, M.L., Busboom, J.R., Cronrath, J.D., Falen, L. and Blankenbaker, A. (2000) Effects of graded levels of potato by-products in barley-and corn-based beef feedlot diets: I. Feedlot performance, carcass traits, meat composition, and appearance. J. Anim. Sci., 78(7): 1829-1836.

24. Petit, H.V. (2000) Effect of whole and rolled corn or barley on growth and carcass quality of lambs. Small Rumin. Res., 37(3): 293-297.

25. Noon, C.D., Seoane, J.R. and Scott, S.L. (1998) The use of corn and barley in diets for veal calves: Effects on performance diet digestibility and carcass quality. Can. J. Anim. Sci., 78(3): 351-358.

26. McAllister, T.A. and Ribeiro, G. (2013) Microbial strategies in the ruminal digestion of starch. In: $50^{\text {th }}$ Annual Meeting of Brazil Animal Science, Campinas, Brazil.

27. Ebrahimi, R., Ahmadi, H.R., Zamiri, M.J. and Rowghani, E. (2007) Effect of energy and protein levels on feedlot performance and carcass characteristics of Mehraban ram lambs. Pak. J. Biol. Sci., 10(10): 1679-1684.

\section{$* * * * * * * *$}

